
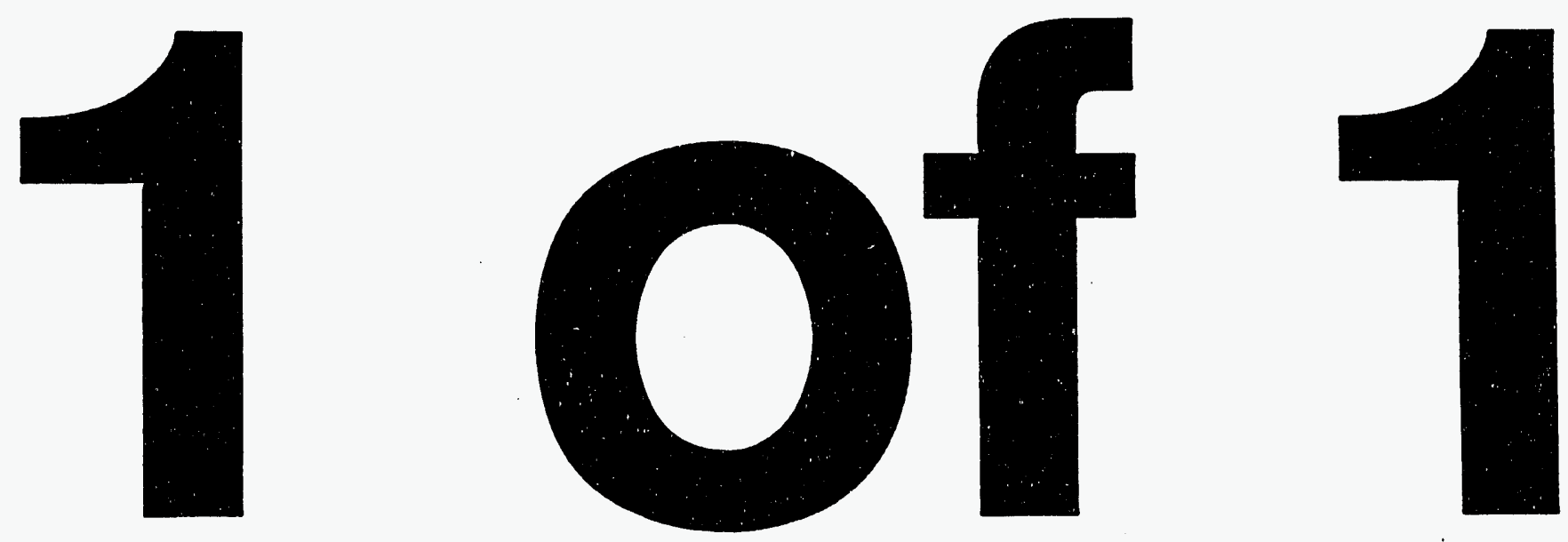
HANFORD CODE $C .+46 \mathrm{C}$

\section{General Ehectaic}

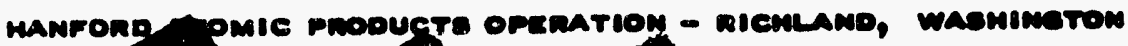

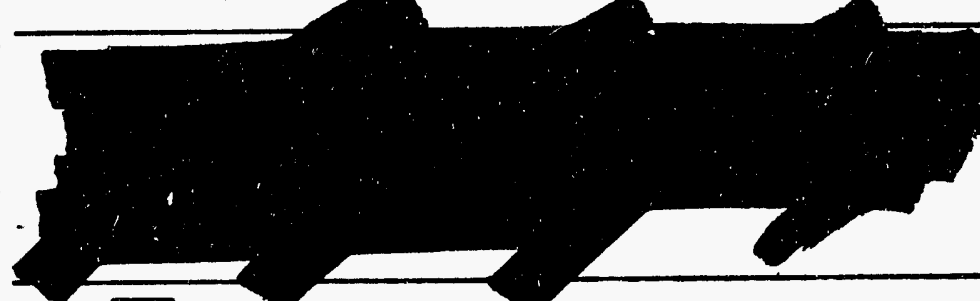

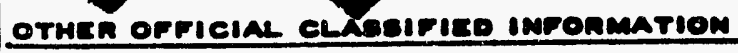

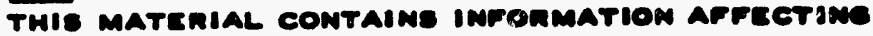
THE NATIONAL. DEFENe or THE UNITED BTATES

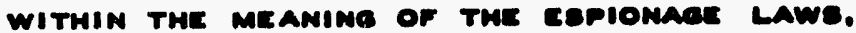

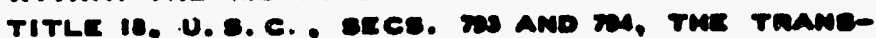

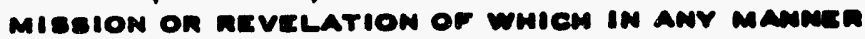
to AN UNAUTHontzed PEngon is pnowibited ov LAN. Tres

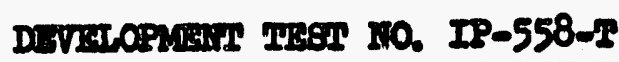

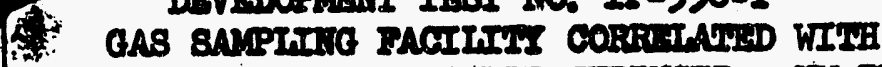

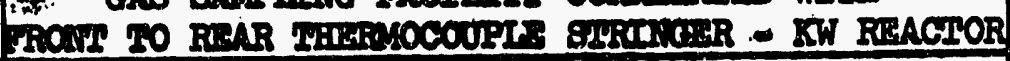
.' ' AUTroon

ecrice amo copr no.

J. R. Cooke

R. I. Basrs JAN 41962

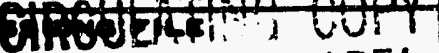
RECEIII- $\div$ AREA

Oine

Decomber 20, 1962 Document mo. घh- 75973 Rtounis i 


\section{DECLLSSSFIED}

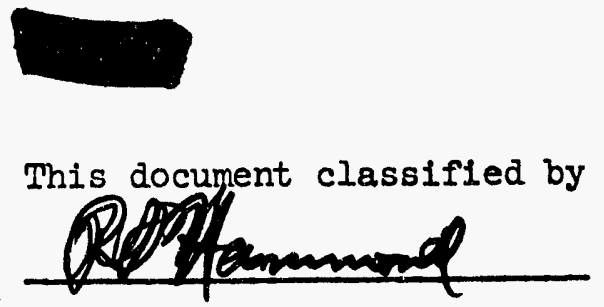

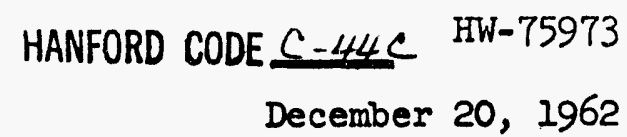

This document consists of 7 pages.

DEVELOPMENT TEST NO. IP-558-T

GAS SAMPLING FACILITY CORRELATED WITH

FRONT TO REAR THERMOCOUPLE STRINGER - KW REACTOR

J. P. Cooke

MECHANICAL DEVELOPMENT

R. E. Baars

PROCESS TECHNOLOGY
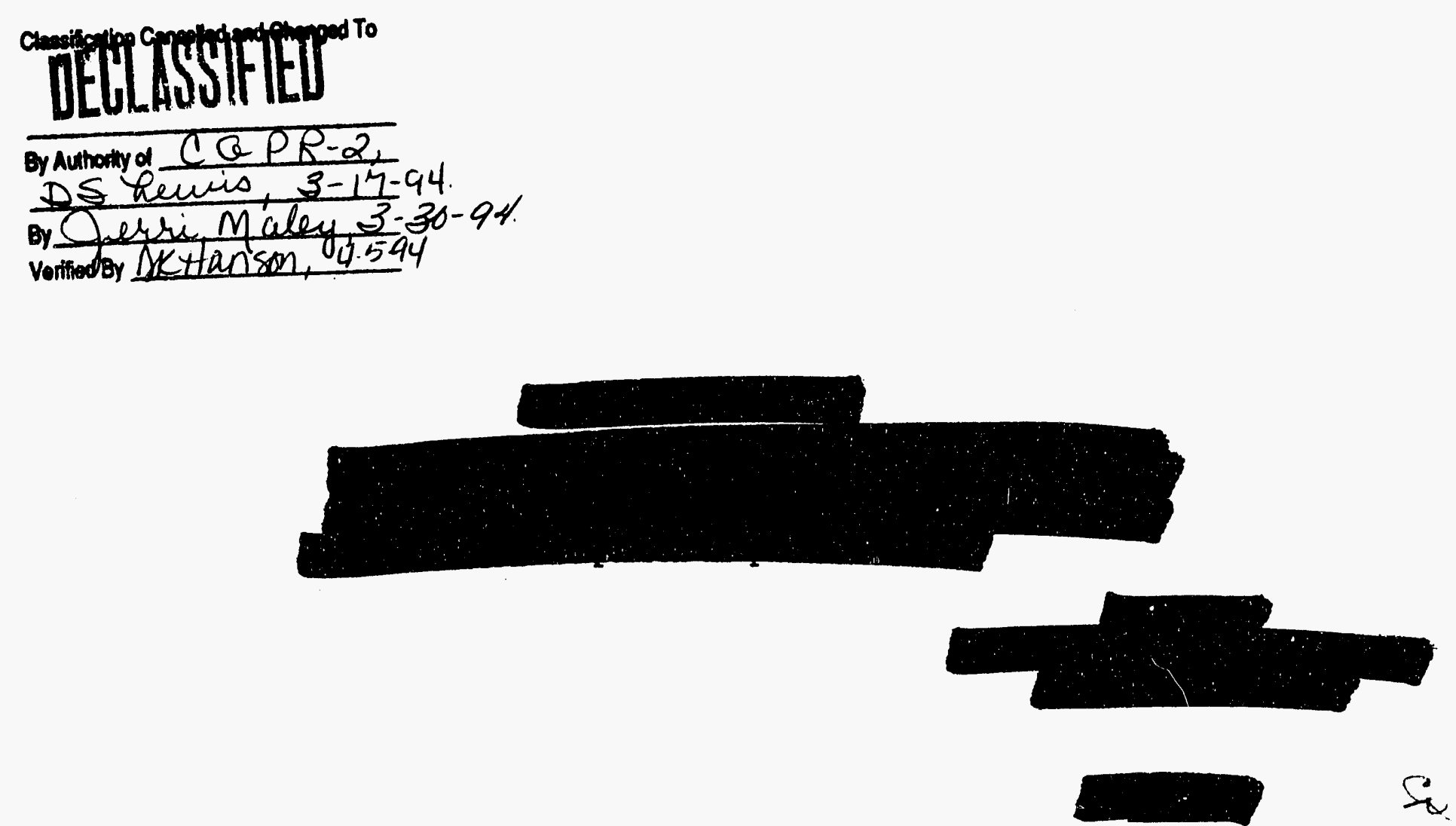


\title{
DEELLSSFFIED
}

HW- 75973

\author{
DEVELOPMEHN TIEST NO. IP-558-T \\ GAS SAMPLING FACILITY CORRISIATHD WITH \\ FRONT TO REAR THERMOCOUPLE STRINGER - KW REACTOR
}

\section{OBJECIIVE}

This test authorizes the installation of sampling tubes in the vacant positions in one of the two front-to-rear graphite stringers. to be installed in KW Reactor in January 1963. These. IInes w1ll permit withdrawal of a gas sample from the active zone at a point where the graphite temperature $1 \mathrm{~s}$ beling measured. Analysis of this gas sample on the gas chromatograph and on a new catalyt1c oxygen-hydrogen instrument $1 \mathrm{~s}$ expected to y1eld valuable information on graphite burnout versus temperature and gas quality.

II. BASIS AND JUSTIFICAIION

PITA IP-20-I establ1shes a temperature $11 \mathrm{mit}$ of $850^{\circ} \mathrm{C}$ in the 0.130 corirag zone extending across the front of the $K$ Reactors. One problem associated with these high temperatures is the possiblilty of sufficiently high watervapor graphlte reaction rates to slgniflcantly weaken the graphite moderator. As a result of the extensive channel reconditioning planned for zirconfum retubing, the central portions of the stack may also be subjected to temperatures of the order quoted above. Thus, a definite resolution of the potential water-vapor graphite reaction becomes yet more 1mportant.

Useful information on thls subject may be obtained by sampling and andiyzing the reactor atmosphere at varlous points in-reactor. This Development Test proposes the ! nclusion of two 1/8" dlameter, 410 stainless steel tubes with one of the two front-to-rear stringers to be Installed shortly in KW (under the authorization of the aforementioned PITA. One of these wlil be used to sample reactor gas at a polnt just within the front of the stack and one to sample reactor gas at the downstream end of the 0.130 coring zone. Analys1s of the gas samples for $\mathrm{O}_{2}$ and water-vapor concentration will provide speclfic information on the depletion of each across the 0.130 corling zone, and thus, on the proportion of each which reacts in the 0.130 zone. Analysis for the reaction products $\left(\mathrm{CO}, \mathrm{H}_{2}\right.$ and $\mathrm{CO}_{2}$ ) from a zone of known temperature within the reactor Is also expected to yleld significant information on the extent of reactions between graphite and gas 1mpurit1es. If this approach proves feaslble, an additional 1mportant technlque will be avallable for assessing the mechanism and Importance of the various potential oxidation reactions.

III. GENERAL PROCEDURE

Two sections of Series 410 , stalnless steel ( $12 \%$ chromium and without nickel content) w1ll be included w1th the bundle of thermocouple w1res. The tubing Is the same size (I/8" O.D.) as the thermocouples, one section will terminate at the same point as thermocouple I-I (two feet 1nto the stack) and the other at the same point as thermocouple I-4 (elght feet into the stack). The tubing

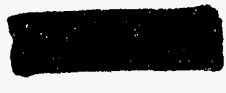




\section{DECLLLSSFIFE}

EW-75973

W11 be brought out of the plle in the same fashion as the thermocouples and will terminate $i_{2}$ tro of the three vacant spots of the flange. The gas seal around the tube will ke made in the same fashion as the thermocouples. The outer end of each tube vill be provided with a Hoke valve. Copper tubing $\left(3 / 16^{\prime \prime} 0 . D_{0}\right)$ will be installed from the Hoke valves across the face of the reactor (behind the gunbarrel flanges) to the $X$ level where connections to the molsture analyzer will be located. Tygon tubing will be used from the $X$ level to conduct gas to the chromatograph to analyze for other components. Analysis of the gas will also be made with a semiportable sensitive hydrogen and oxygen analyzer which is being placed in service by FEO.

Figure 1 shows a sketch of the tubing installation in the stringer; Figure 2 shows the hookup to be used at the molsture analyzer. Reactor gas which has passed through the molsture analyzer will be exhausted to the building exhaust duat on the $X$ level.

Because the reactor gas includes activated atoms, some increase in dose rates will be experienced on the front face when gas is being withdrawn through the tubes. It is estimated that a maximum dose rate of the order of $6 \mathrm{mr} / \mathrm{hr}$. at one foot ill be seen from each tube through which gas is being witharawn.

\section{DETAILED PROCEDURE}

1) In preparation of the thermocouple stringer, the tubing will pass through vicant holes in the shielding plugs and seal in exactly the same way as the thermocouples. (There are 10 thermocouples and 13 holes available.)

2) Exterior ends of tubing will be provided with a needle valve (Hoke type) and will also be capped. These termination fittings will project about silx inches from the thermocouple junction box on the front nozzle flange. Samples will be handled through copper lines from this point to the $X$ level. From the $X$ level, so.mples $w 111$ be handled by tygon lines. (It is anticipated that the copper lines can be installed during operation and thus require no outage time.)

3) When the TC Stringer eventually has to be removed for disposal, the tubing w111 go with 1 t。

\section{HAZARDS}

The stalniess steel rill be activated to approximately the same radiation level as the metal portion of the thermocouples on a welght for welght basis. Both are relatively short lines. While they will increase the level of activity, the increase. will not be such as to appreciably affect removal prow cedures for the stringer.

All valves in the sampling lines rili be kept closed when the gas is not being sampled to insure anatcet 1 in in-ieakage. The extreme sensitivity of the inst munents wili insure against leaks in valves and copper lines thus prcviling a continuous leak test during use to insure against inadvertent leaks.

VI. PROCESS STAIDARDS

All provisions of the Process Standards and PITA IP-20-I remain in full force. Deviations from Design Change No. 654 as required to accomplish the inclusion 
of the two samritng lines on the one stringer, sre authorized by this Development Test.

VII. Costs

The materials required to accomplish this test will be supplied by FEO. The costs of installing the tubing in the stringer will be borne by KW Processing Operation. The costs of installing the other appurtenances and of performing analysis $\mathrm{wlll}$ be borne by $\mathrm{FEO}$. No outage time will be incurred as $\varepsilon$ result of this test.

\section{VIII: WAFIDILITIES}

KW Processing wlll be responsible for installing the 400 series stainless tubing and valves, and for operating continulty and safety of the reactor. Facilities Engineering Operation will supply the tubing and obtain analyses of gas samiles vitidrewn. Rasearch and Engineering vill be responsibje for interpreting the resulits of the experiment and ror recomenations as warranted.

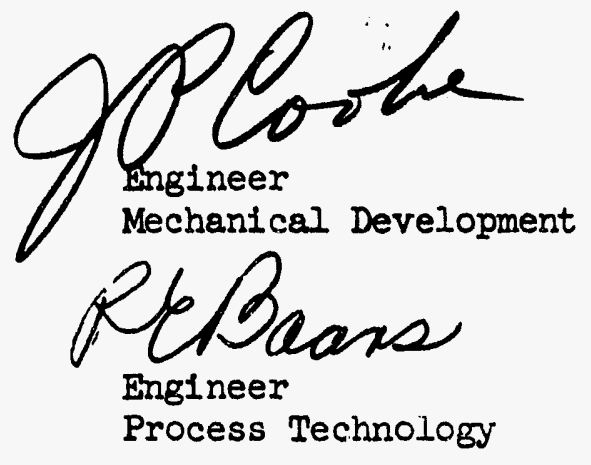

JP Cooke:RE Baars:hr 


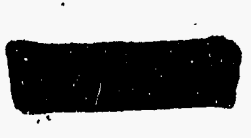

To: Distribution

DECLASSIFIED

HW-75075

December 20 , 19602

DEVELOPMENT TEST NO. IP-558-T

GAS SAMPLING FACILITY CORRELATED WITH

FRONT TO REAR THERMOCOUPLE STRINGER - KW REACTOR

APPROVALS

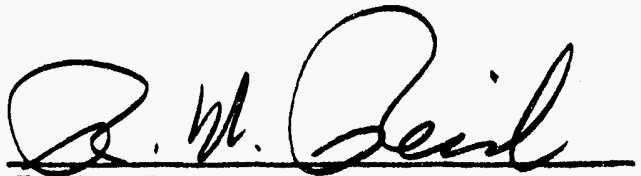

$\mathrm{R}_{\text {. }}$ W. Re id, Manager

Process Technology $\zeta$

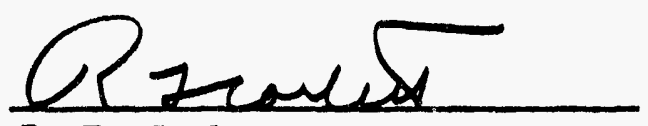

R. F. Christ, Manager KW Processing

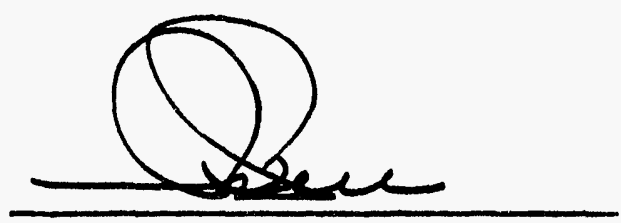

R. S. Bell, Manager $\mathrm{K}$ Reactors

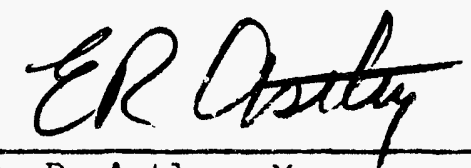

E. R. Astley, Manager Applied Reactor Engineering 


\section{DEPIISPEIED}

$-6-$

HW- 75973

UNCLASSTIPISD VIEN DETACHED

FROM DOCUNENT NO. 75973
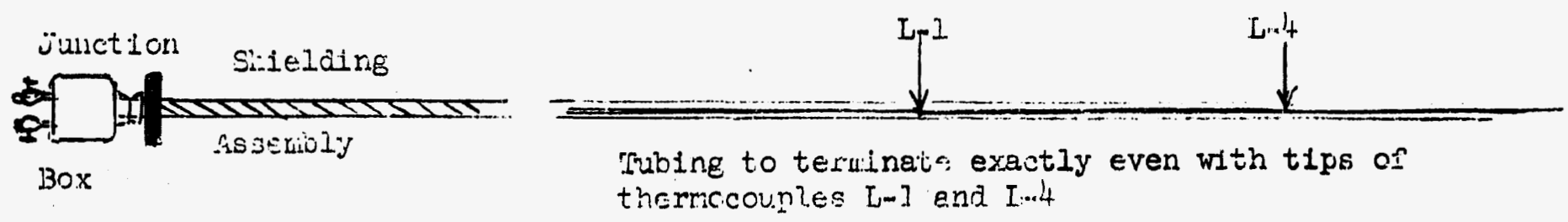

i. eure 1

Over-all Assembly of mubing in

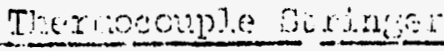

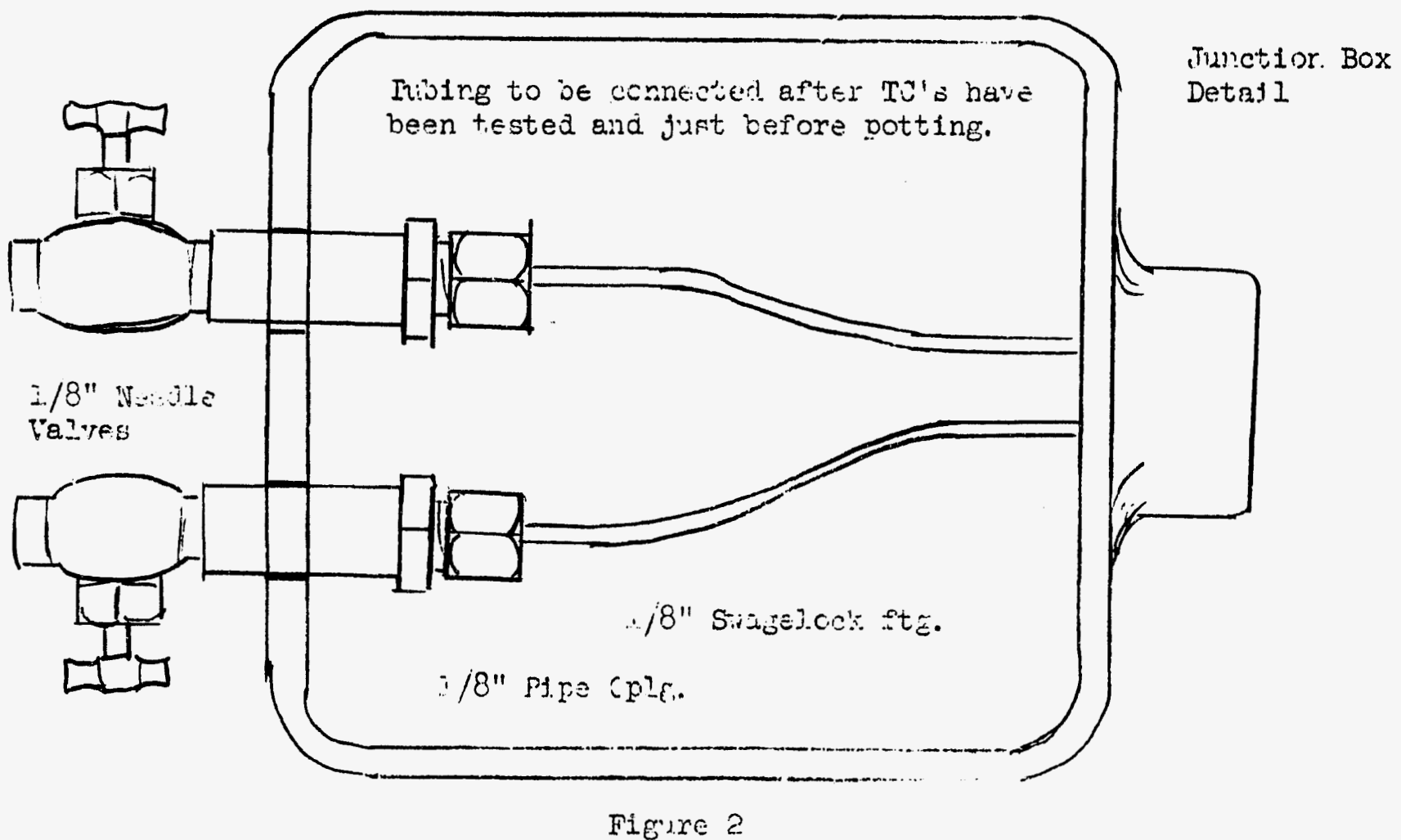

Figure 2 
DISTRIBUTION

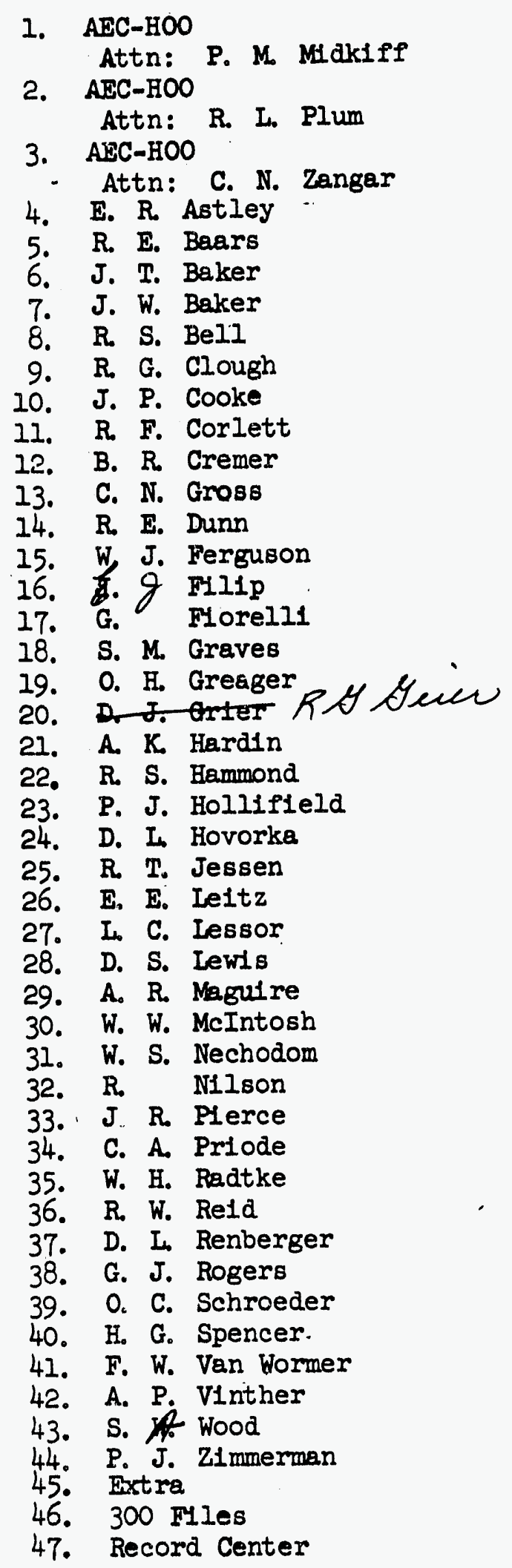



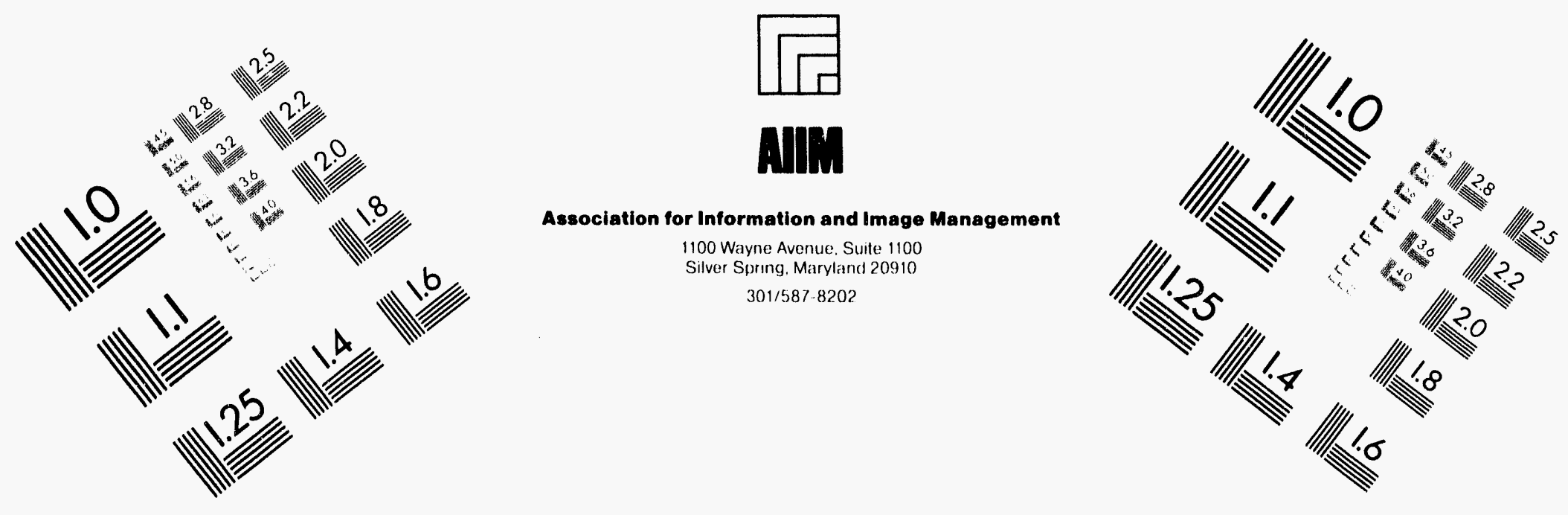

\section{Centimeter}

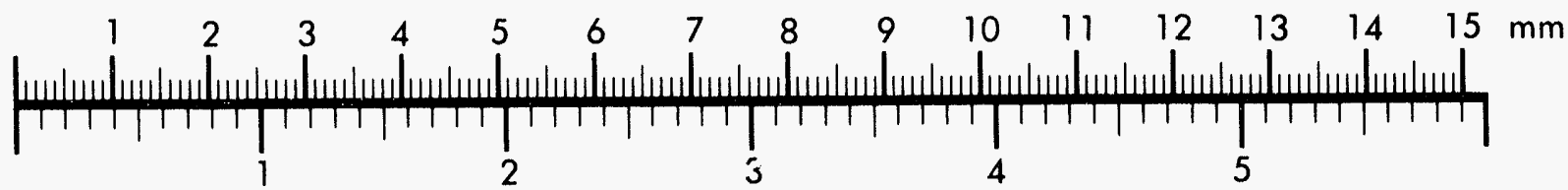

Inches
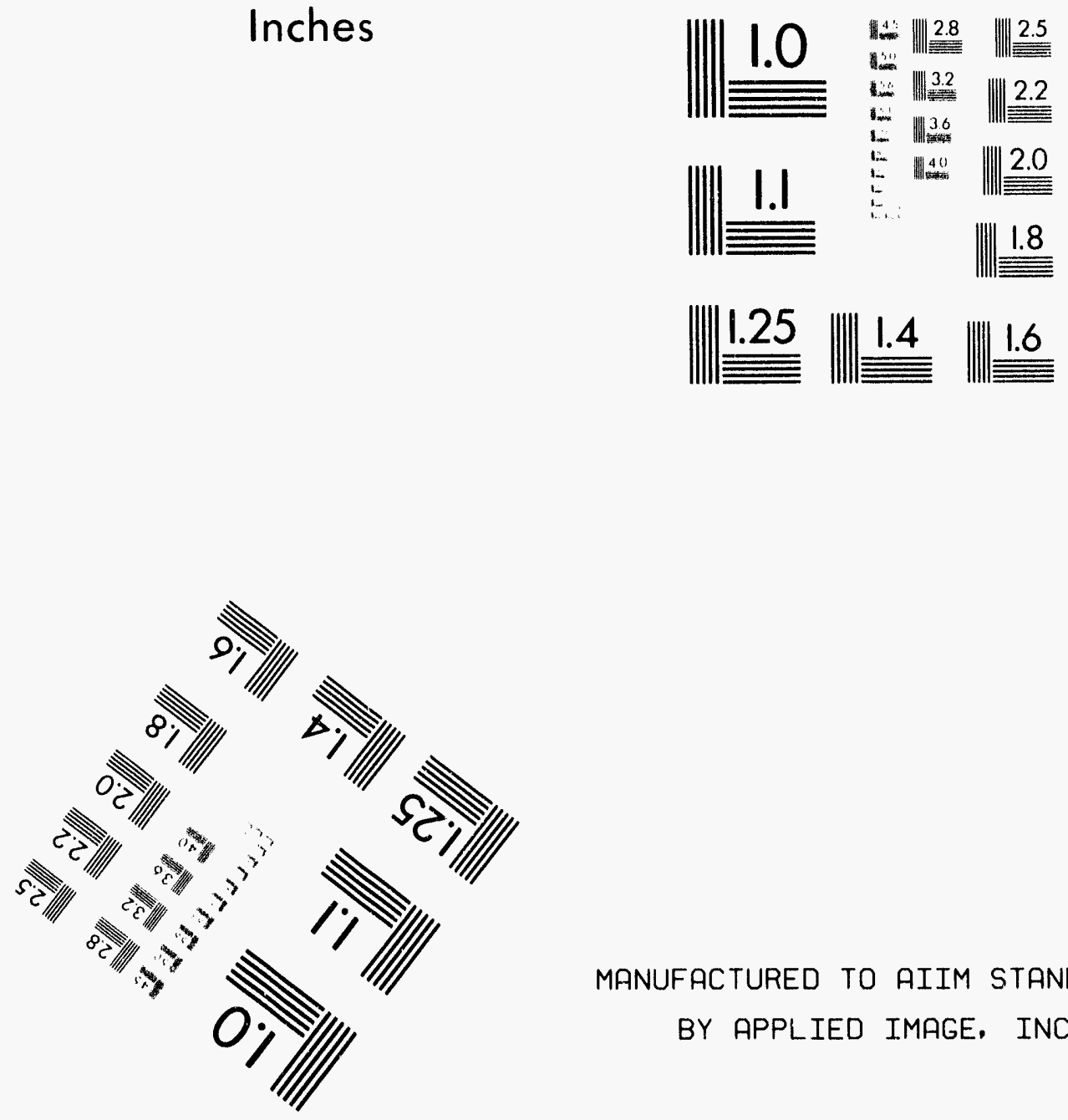

MANUFACTURED TO AIIM STANDARDS

BY APPLIED IMAGE, INC.

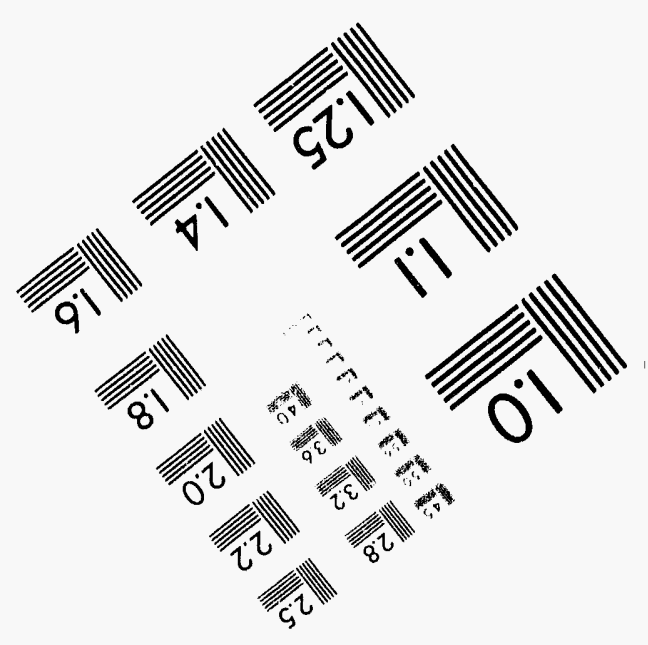




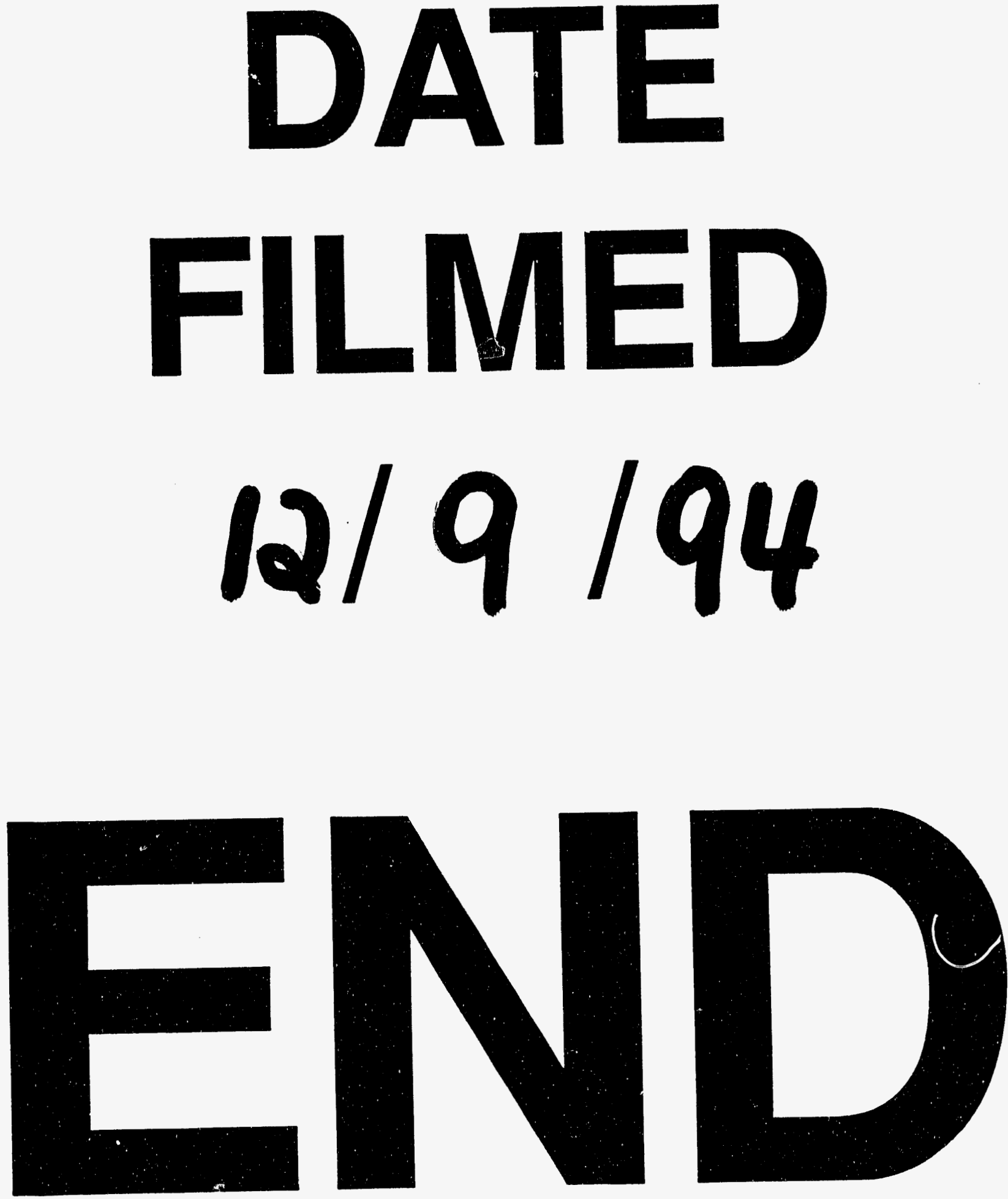